\title{
混合気希釈がノック強度に及ぼす影響
}

\section{Effect of fuel-air mixture dilution on knock intensity} \\ Mitsuaki OHTOMO*1 ${ }^{*}$ Seiji YAMAMOTO*1 and Hiroshi MIYAGAWA*1 \\ ${ }^{* 1}$ Toyota Central R\&D Labs. Inc., \\ 41-1 Yokomichi, Nagakute-shi, Aichi 480-1192, Japan
}

大友 光彰 ${ }^{* 1}$, 山本 征治 ${ }^{* 1}$, 宮川 浩 ${ }^{* 1}$

\section{Received 20 April 2016}

\begin{abstract}
Effect of fuel-air mixture diluted by inert gas on knock intensity was investigated by using a rapid compression and expansion machine. Dilution of fuel-air mixture decreased knock intensity. As the dilution ratio became high, increase in input heating value did not affect knock intensity too much although it shortened auto-ignition delay. Knock intensity is assumed to correlate with the pressure rising rate when the auto-ignition occurs. Knock intensity was shown as a function of the maximum pressure and the maximum temperature which affect the high temperature oxidation reaction rate.
\end{abstract}

Key words : Ignition, Chemical reaction, Internal combustion engine, Knock, Pressure rising rate

\section{1. まえがき}

近年, 自動車からの $\mathrm{CO}_{2}$ 排出低減競争が激しさを増しており, エンジンの熱効率向上をねらいとした様々な研 究が行われている. 火花点火式エンジンにおいては，ノックの抑制が長年の大きな課題である.八ックは，燃焼 室内において火花点火による火炎伝播然焼途中にエンドガスが自着火し, それによって圧力振動が発生する現象 である.この圧力振動は燃焼室にダメージを与える可能性があり，そのためにノックの発生を抑制する必要があ る. 多くの場合，点火時期を遅らせる，圧縮比を下げるなどの方法でノックを抑制している．しかしながら，こ れらは熱効率を低下させる要因でありエンジンにとっては望ましくない.

点火時期の遅延や圧縮比の低下は，未燃混合気の圧力や温度を下げることが目的であり，それによってエンド ガスを自着火させず, 圧力振動の発生を防いでいる.一方, HCCI などの圧縮自着火燃焼では, 燃料の自着火を 積極的に利用している，例えば，図示平均有効圧 $1 \mathrm{MPa}$ を超える条件においても，ノックを発生せずに燃焼させ ることが可能であることが示されている (Inagaki et al., 2006, Splitter et al., 2010). また，火炎伝播を用いた燃焼に おいても, エンドガスが自着火してもノックが発生しない条件が存在することが知られている(Azimov et al., 2011). ただし，負荷を増大させたり，燃焼時期を進角させると容易にノックに移行するため，その成立条件は限定され ていると考えられる.

このように，混合気が自着火しても必ずノックが発生するわけではないものの，その条件についてはいまだ不 明な点が多い，いずれの自着火を用いた燃焼においても，混合気が EGR や空気によって希釈された条件で然焼 していることから，混合気希釈が自着火時のノック発生に影響を及ぼしていると考えられる.

そこで本研究では，特に EGR を想定して，不活性ガスによる混合気の希釈が，自着火時のノック強度に及ぼす 影響を調べ，ノック強度の支配因子を明らかにすることを目的とした.

No.16-00185 [DOI:10.1299/transjsme.16-00185], J-STAGE Advance Publication date: 8 December, 2016

${ }^{* 1}$ 正員, (株) 豊田中央研究所（广480-1192 愛知県長久手市横道 41-1）

E-mail of corresponding author: mohtomo@mosk.tytlabs.co.jp 


\section{2. 混合気自着火に伴う圧力上昇率の変化}

局所的な熱発生により空間的に圧力分布が生じるのは，自着火による圧力上昇が，周囲への膨張によって緩和 されない場合であると考えられる．この場合に燃焼室内で圧力波が発生し，ノックに至ると考えられる．すなわ ち, 自着火による圧力上昇がノックを発生させる加振力になる. 圧力上昇率 $(d P / d t)$ は, 次の式であらわ寸こと ができる.

$$
\frac{d P}{d t}=\frac{\kappa-1}{V} \frac{d Q}{d t}-\frac{\kappa P}{V} \frac{d V}{d t}
$$

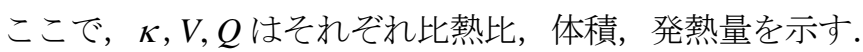

したがって, 自着火時の反応, 寸なわち高温酸化反応による発熱速度を低下させることで, 圧力上昇率が低下 し, その結果ノック強度も低下寸ると考えられる. よって, 従来のノック発生の有無は, 自着火発生の有無で議 論されているが，圧力上昇率を下げることで自着火が発生してもノックの発生を抑制できる可能性がある.

本研究では, 初めに混合気の自着火計算を実施した。燃料のオクタン価や混合気希釈が高温酸化反応による圧 力上昇に及ぼす影響を基礎的に調べ, 自着火発生の目安となる自着火遅れと比較した. 次に, 急速圧縮膨張装置 (RCEM) を用いて，自着火発生時のノック強度について調べ，その支配因子を考察した.

\section{3. 自着火に伴う圧力上昇}

\section{$3 \cdot 1$ 計算方法及び条件}

本章では, CHEMKIN II の SENKIN を用いた 0 次元計算を行った. 反応スキームには, PRF (Primary Reference Fuel, ノルマルヘプタン，イソオクタンの混合燃料) のモデル (Lawrence Livermore National Laboratory, 2014) を使用し た. 計算は定容条件で行い, 初期温度を $800 \mathrm{~K}$, 当量比を 1 とした. 図 $1(\mathrm{a})$ に, 初期圧 $2.0 \mathrm{MPa}$, 希釈率 $0 \%$ のソ オクタン $\left(\mathrm{iC}_{8} \mathrm{H}_{18}, \mathrm{RON100)}\right.$ - 空気混合気を自着火させたときの圧力, 温度の時間履歴を，(b)に(a)の一部を拡大し た圧力及び圧力上昇率 $(d P / d t)$ の時間履歴を示す. 計算開始後, 約 $32 \mathrm{~ms}$ で急激に圧力と温度が上昇した. $d P / d t$ は単調に上昇し, 最大值をとった後, 単調に減少した. この $d P / d t$ の最大值 $\left((d P / d t)_{\max }\right)$ を各種混合気で比較した. また，反応により温度が $1200 \mathrm{~K}$ を超えたタイミングを混合気の自着火遅れ $(\tau)$ とした.
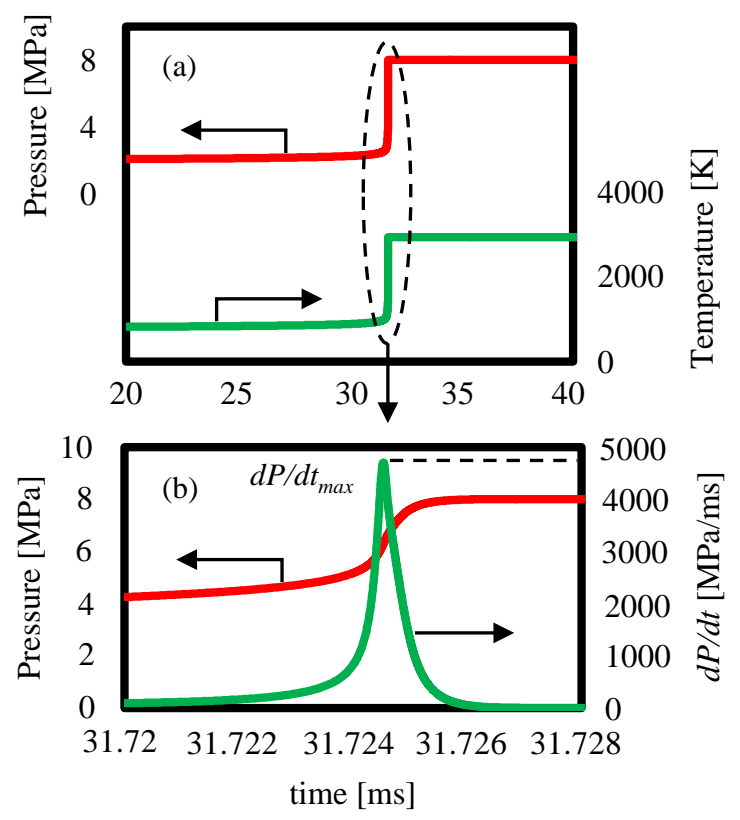

Fig.1 History of Calculated Pressure and Pressure Rising Rate $\left(\mathrm{iC}_{8} \mathrm{H}_{18} /\right.$ Air Mixture without dilution) 


\section{$3 \cdot 2$ 計算結果}

初めに，イソオクタンの他に，ノルマルヘプタン $\left(\mathrm{nC}_{7} \mathrm{H}_{16}, \mathrm{RON} 0\right)$, メタン $\left(\mathrm{CH}_{4}, \mathrm{RON130)}\right.$ をそれぞれ然料と して，燃料による $\tau$ や $(d P / d t)_{\max }$ の違いを比較した. 次に，イソオクタン-空気混合気を $\mathrm{N}_{2}$ または $\mathrm{CO}_{2}$ により希 䣋し，希釈の影響を調べた。いずれの条件でも，混合気の総発熱量を図 1 に示寸条件と同一になるように，初期 圧を調整した，すなわち，希釈率を増加させるにしたがって，初期圧を高くした.

図 2 に, 各燃料での $\tau$ と $(d P / d t)_{\text {max }}$ の関係を示す. $\tau$ は $\mathrm{nC}_{7} \mathrm{H}_{16}<\mathrm{iC}_{8} \mathrm{H}_{18}<\mathrm{CH}_{4}$ の順に大きくなった. この順番は, 燃料のオクタン価の順と一致する.一方, $(d P / d t)_{\max }$ は燃料による違いはみられず, オクタン価は影響していない. 図 3 に，燃料が $\mathrm{iC}_{8} \mathrm{H}_{18}$ の場合の $d P / d t$ と合わせて $\mathrm{iC}_{8} \mathrm{H}_{18}$ 及び $\mathrm{CO}_{2}$ の時間変化を示す. $\mathrm{iC}_{8} \mathrm{H}_{18}$ は初期状態に対する 消費率, $\mathrm{CO}_{2}$ は反応終了時の割合に対する生成率として表す. $(d P / d t)_{\text {max }}$ のタイミングは, $\mathrm{CO}_{2}$ 割合が急激に増加 している時期とほぼ一致し，反応の後期であることが推察される． $\mathrm{iC}_{8} \mathrm{H}_{18}$ はこれよりも早い時期に消費されてい る. したがって, 酸化が進み燃料が低分子化している時期に $\mathrm{dP} / \mathrm{dt}$ が最大になるため, 炭化水素燃料ではオクタ ン価が異なっても $(d P / d t)_{\max }$ は変化しないと考えられる. 次に, イソオクタン一空気混合気を $\mathrm{N}_{2}$ または $\mathrm{CO}_{2}$ で希 釈した. 希釈率 (vol.\%) に対する $\tau$ 及び $(d P / d t)_{\text {max }}$ の変化を図 4 に示寸. 希釈率と共に $\tau$ は長くなる傾向がみられ る. $\mathrm{N}_{2}$ と $\mathrm{CO}_{2}$ では $\tau$ への影響に大きな違いはない，一方， $(d P / d t)_{\max }$ は希釈率と共に小さくなる. $\mathrm{CO}_{2}$ 希勫の方 が $\mathrm{N}_{2}$ 希勫よりも $(d P / d t)_{\text {max }}$ が小さい. 希釈をしていない場合と比較して, $\mathrm{N}_{2}$ 希釈では $40 \%, \mathrm{CO}_{2}$ では 20\%希釈し た場合に $(d P / d t)_{\text {max }}$ が約 $1 / 10$ に低下しており，混合気の希釈は圧力上昇率に大きな影響を及ぼす．以上のことか ら, $(d P / d t)_{\max }$ は, 自着火発生の目安となる $\tau$ とは異なる変化をすることがわかった.

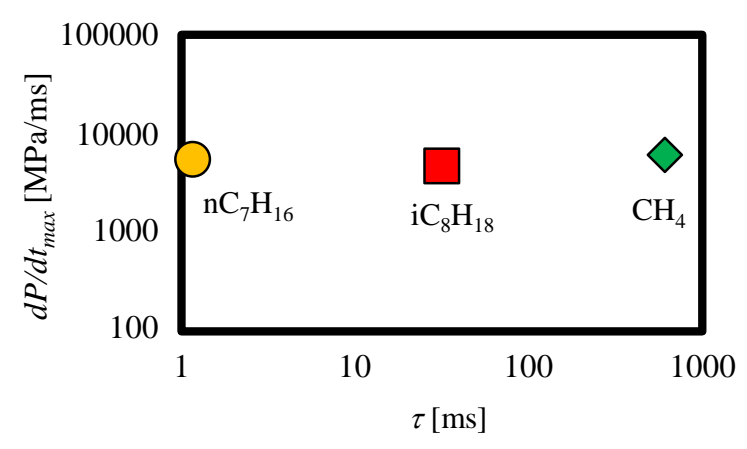

Fig.2 Effect of Fuel on $\tau$ and $(d P / d t)_{\max }$

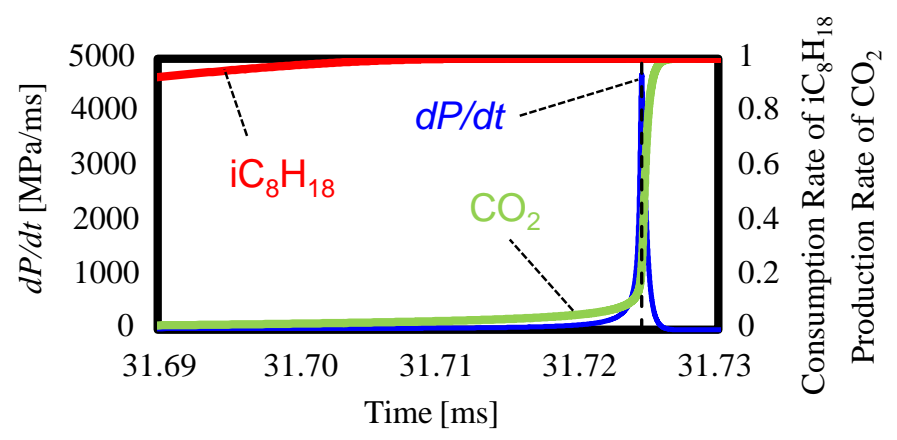

Fig.3 History of $d P / d t$, Consumption Rate of $\mathrm{iC}_{8} \mathrm{H}_{18}$, Production Rate of $\mathrm{CO}_{2}\left(\mathrm{iC}_{8} \mathrm{H}_{18} /\right.$ Air Mixture without dilution) 


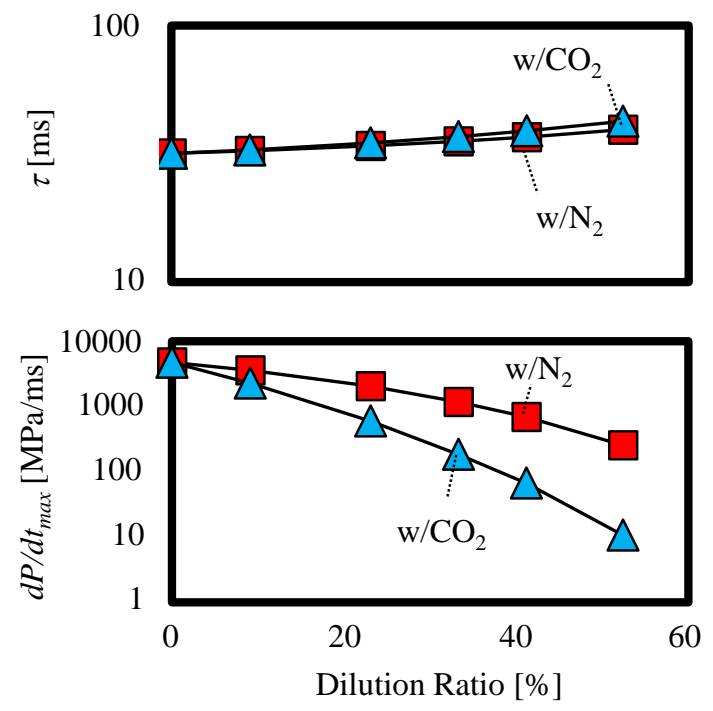

Fig.4 Effect of Dilution Ratio on $\tau$ and $(d P / d t)_{\max } \quad\left(\right.$ Fuel:iC $\left.{ }_{8} \mathrm{H}_{18}\right)$

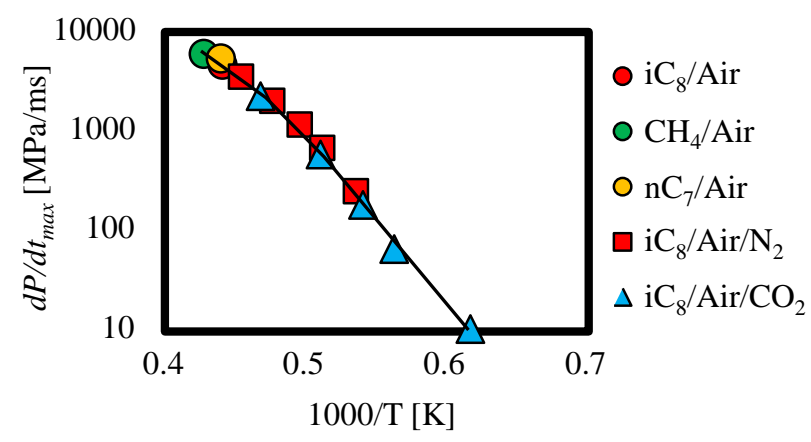

Fig.5 Relationship between 1000/T $T_{(d P / d t) \max }$ and $(d P / d t)_{\max }$

そこで, $(d P / d t)_{\text {max }}$ の支配因子を調べるために, 希勫により $(d P / d t)_{\text {max }}$ が小さくなる原因を考察した. 今回の計算 は定容条件であり, 総発熱量が等しいことから, 式(1)より発熱速度, 寸なわち反応速度, もしくは比熱比が $(d P / d t)_{\max }$ に影響していると考えられる. 反応速度は温度の関数であることから, $(d P / d t)_{\max }$ をその際の温度 $\left(T_{(d P / d t) m a x}\right)$ に対し, アレニウスプロットにより整理し, 図 5 に示す. 混合気の種類によらず, 温度が低いほど, $(d P / d t)_{\text {max }}$ が小さくなる傾向がみられ，両者はほぼ 1 対 1 の関係を示した。混合気希釈は，反応温度を低下させる ため, 反応速度が低下し，その結果 $(d P / d t)_{\text {max }}$ が低下したと考えられる.また, $\mathrm{CO}_{2}$ 希釈と $\mathrm{N}_{2}$ 希釈では, 前者の 方が比熱が大きいため, 反応温度が低く, 反応速度が遅くなり, $(d P / d t)_{\text {max }}$ が小さかったと推察される. 式(1)に示 したように, $\mathrm{CO}_{2}$ 希勫による比熱比の低下自体も圧力上昇率を低下させるが, 希釈による比熱比の違いは数\%で あり，この違い自体が数十倍の圧力上昇率の違いに及ぼす寄与は小さいと考えられる.

次に，希勫による反応時の圧力上昇率の低下が，燃焼室内で発生するノック強度に及ぼす影響について，急速 圧縮膨張装置を用いた実験により調べた。

\section{4. 自着火時のノック強度}

\section{$4 \cdot 1$ 実験方法及び条件}

急速圧縮装置による均質予混合気の圧縮自着火は，自着火遅れの計測手段として用いられる，その時の筒内の 圧力計測結果を図 6(a)に示寸．自着火発生時には圧力振動がみられる。これは，均質混合気といえども壁面への 熱の流出などによる温度不均一が原因で局所的な自着火が生じていることに起因すると考えられる. 図 6(b)に計 測圧力をフーリエ変換した結果を示す．特に $6 \mathrm{kHz}$ 前後で強い振幅が確認された．本燃焼室内で発生するノック 
周波数を, 基本振動モード (Hickling et al., 1982) からモード毎に算出した結果を表 1 に示寸. A のモードの周波 数が $6.5 \mathrm{kHz}$ であり, 図 6(b)で振幅の強い周波数とほぼ一致した. したがって, この周波数はエンジンのノックと 類似した圧力振動と考えられる. 今回は，この圧力振動の大きさをノック強度として検討を行った.

図 7 に実験装置を示す．ピストンが BDCにある状態で然焼室内を真空ポンプにより減圧した後, 予混合タン ク内に作成しておいた所定の混合気を導入した. その後, 油圧シリンダにより接続されたコンロッドを動かし， ピストンにより燃焼室を圧縮した，圧縮終了後，ピストンをTDCで停止させることで高温高圧を維持し，混合 気を自着火させた。燃焼室に取り付けた指圧計で計測（サンプリング周波数 100kHz）した燃焼室内の圧力から， 混合気のて及びノック強度を算出した．燃焼室はボアが $85 \mathrm{~mm}$ のパンケーキ型で，圧縮比は 10 とした．圧縮時間 は $25 \mathrm{~ms}$ とした. 燃料にはイソオクタンを用い, 当量比は 1 , 初期温度は $120^{\circ} \mathrm{C}$ した. 燃料-空気混合気は, EGR を想定した体積比 $\mathrm{N}_{2} / \mathrm{CO}_{2}=85 / 15$ のガスにより希釈した.

図 8 に, 図 6 に示した計測圧力の処理の一例を示す.ノック成分を抽出するため, $2.5 \mathrm{kHz}$ で計測圧力をハイパ スフィルタ及びローパスフィルタにより処理した．その結果が図 8(a)及び(b)である．八イパスフィルタで処理す ると自着火が発生したタイミングで振幅が確認された. この振幅の最大值と最小值の差をノック強度 $(K I)$ と定 義した. またローパスフィルタで処理した波形における最高圧力を $P_{\max }$ と定義し， $P_{\max }$ から状態方程式により求 めた平均温度を最高温度 $T_{\max }$ と定義した. 図 8(c)は(b)から熱発生率を求め, 着火時期付近を拡大した図である. 前章の計算結果と異なり燃焼室内に温度分布があるため, 熱発生率から自着火遅れを定義し, 熱発生率が 70J/ms

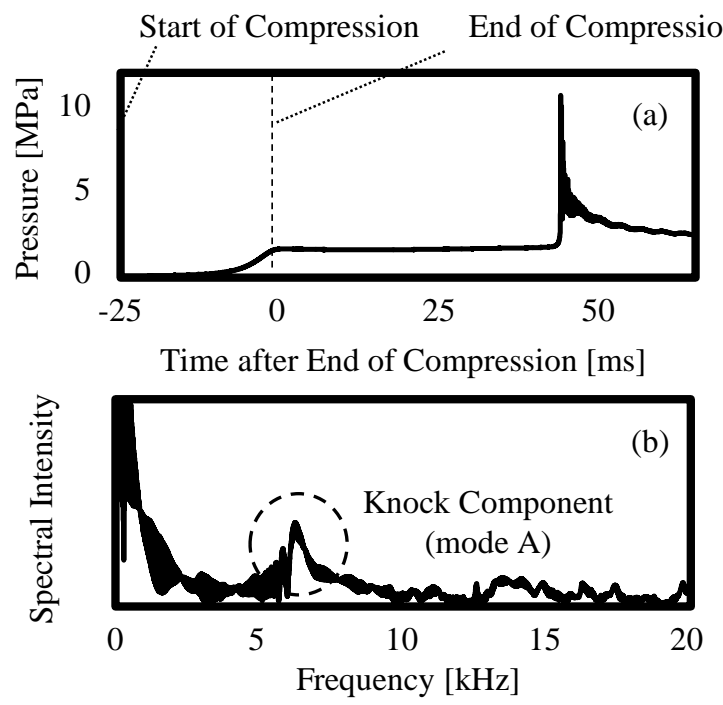

Fig.6 Example of (a) Measured Pressure and (b) Result of FFT using RCEM

Table 1 Relationship between Oscillation Mode and Knock Frequency in RCEM

\begin{tabular}{l|l|l} 
Oscillation Mode & Frequency $[\mathrm{kHz}]$ \\
\hline & & \\
\hline
\end{tabular}


を越えた時間を自着火発生時期，圧縮終了後から自着火発生時期までの時間を $\tau$ とした.

実験では, 各投入発熱量において希橎率 (vol.\%, D) が $\tau$ や KIに及ぼす影響を調べた. 投入発熱量は初期圧に よって調整した，以下では，各条件における投入発熱量 $(Q)$ は，希釈率 $0 \%$, 初期圧 $0.10 \mathrm{MPa}$ の場合の投入発熱 量 $\left(\mathrm{Q}_{\mathrm{std}}\right)$ で正規化した值 $\left(\right.$ 投入発熱量比 $\left.Q^{*}=Q / Q_{\text {std }}\right)$ で示した.

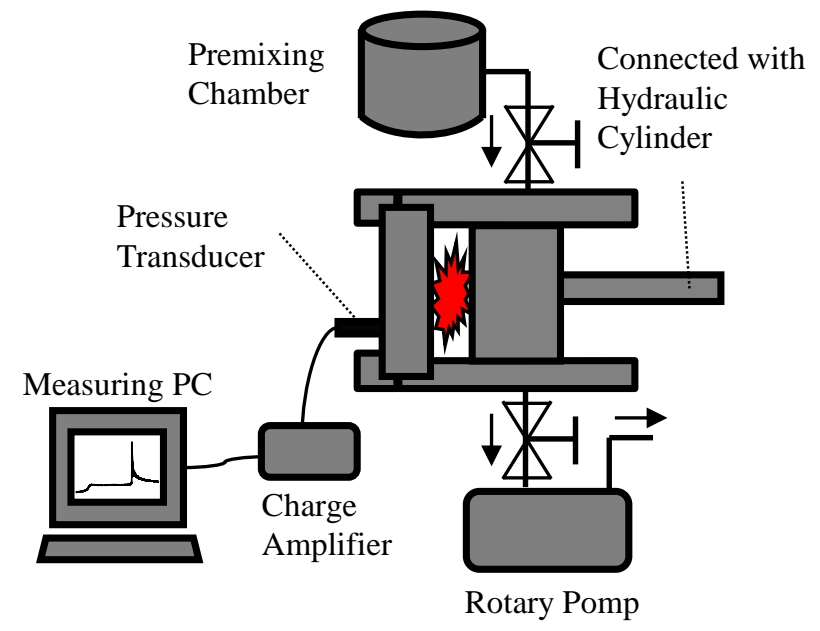

Fig.7 Experimental Apparatus
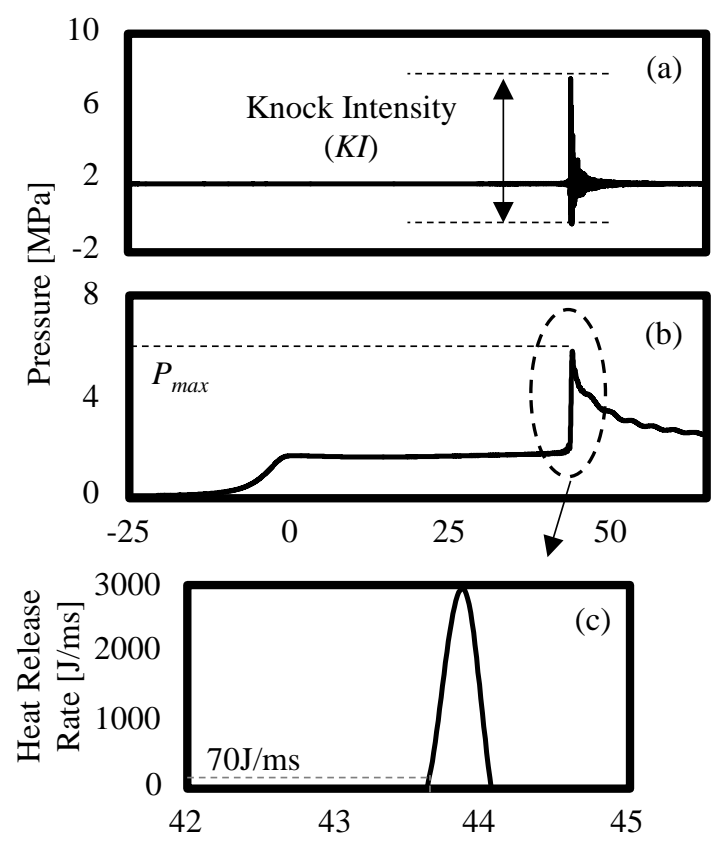

Time after End of Compression [ms]

Fig.8 Example of Pressure Analysis (a) Pressure through High-Pass Filter (b) Pressure through Low-Pass Filter (c) Rate of Heat Release calculated using (b)) 


\section{4-2 実験結果}

図 9 に投入発熱量比 0.75 で希釈率 $0 \%$ と 60\%, 及び投入発熱量比 1.0 で希釈率 $60 \%$ での計測圧力及びハイパス フィルタ処理後の圧力を示す. 投入発熱量比 0.75 の条件で, 希釈率を $0 \%$ から $60 \%$ にると, 混合気のガス量が 多いために着火前の圧力は高くなるものの， $\tau$ は長くなり，KI は小さくなった. 希釈率 $60 \%$ の条件で，投入発熱 量比を 0.75 から 1.0 にすると， $\tau$ が短くなり，KI は増加した. この時の $\tau$ と $K I$ を投入発熱量比 0.75 ，希釈率 $0 \%$ の結果と比較すると， $\tau$ が短くなるにもかかわらず，KI が低下した．図 10 に，希釈率 $0 \%, 40 \%, 60 \%$ て投入発熱 量を変化させたときの $\tau$ と $K I$ の変化を示す， $\tau$ については，いずれの希釈率でも投入発熱量が増加すると短くな

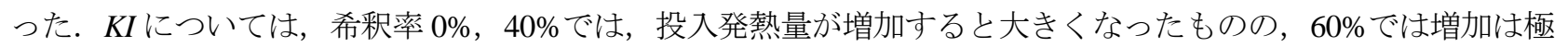
めて小さかった。同投入発熱量では，希釈率が高いほど KI は小さくなり，特に発熱量が高い条件で KIの違いが 大きかった.

他の希釈率でも実験を行い，希釈率，投入発熱量比に対する等 $\tau$ 線と等 $K I$ 線を求めた結果を図 11 に示す. 破 線で示す 3 本の等 $\tau$ 線はほぼ直線であり，その傾きに大きな違いはなかった．すなわち，投入発熱量が大きいほ

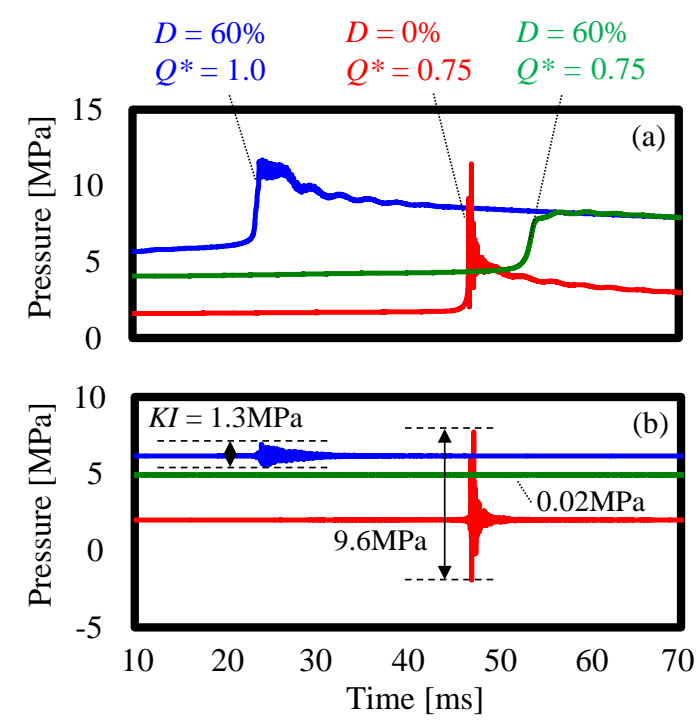

Fig.9 Comparison of $\tau$ and (dP/dt) $\max ((a)$ Measured Pressure (b) Pressure through High-Pass Filter)

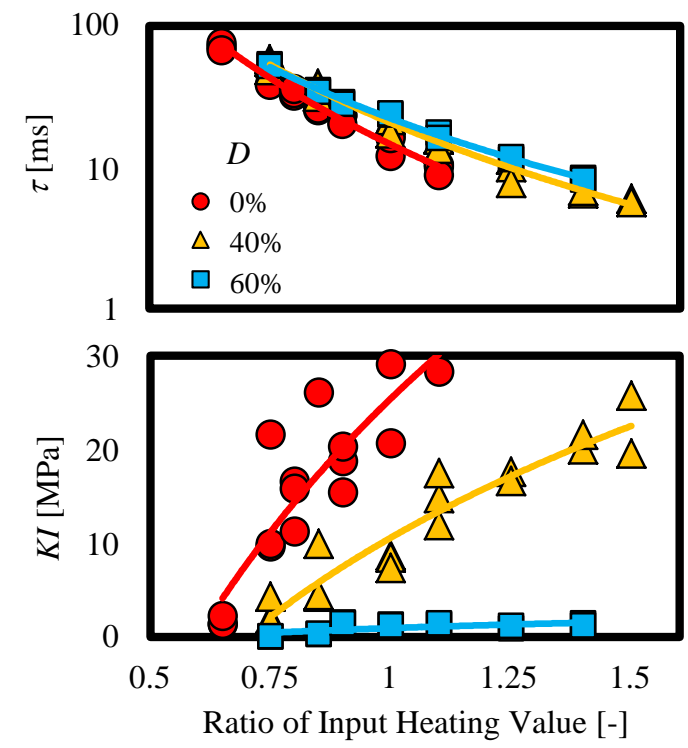

Fig.10 Effect of Ratio of Input Heating Value on $\tau$ and $K I$ 
ど，また希釈率が低いほど，てが小さくなる傾向を示していた．特に，投入発熱量の増加による った，一方，実線で示寸 3 本の等 $K I$ 線は傾きが一定ではなく，条件により変化していた，おおよそ希釈率 $30 \%$ 以下では, 投入発熱量を増加させると KI が大きくなり, 希釈率を増加させても KI はあまり変化しなかった. し かしながら，希釈率 30\%以上では，希勫率を増加させると KI が大きく低下寸るが，投入発熱量を増加させても $K I$ の変化は小さく, わずかに増加した. 寸なわち, 高希釈率では高負荷条件でも, $K I$ を抑制しながら混合気を自 着火させることが可能であることがわかった.

前章で示した自着火計算結果から，不活性ガスによる混合気の希釈は，着火反応時の温度を下げ，高温酸化反 応による発熱速度を低下させることにより，KI を低下させたと推察される. また，投入発熱量を変化させると混 合気の密度も変化するため, 高温酸化反応速度は, 反応時の温度のほかに, 圧力も大きく影響していると考えら れる. そこで圧力と温度を $P_{\text {max }}$ と $T_{\text {max }}$ で代表し, $P_{\text {max }}$ 及び $T_{\text {max }}$ を $K I$ 毎に記号により分類した結果を図 12 に示寸. $P_{\max }$ または $T_{\max }$ が大きくなるほど, $K I$ が大きくなる傾向がみられた. 図中に, 実験結果から求めた $K I$ の等值線 を合わせて実線にて示す. 2000K 以上では圧力影響が強く, それ以下の温度では温度低下と共に急激に KI が低下 した．図中の破線は，等投入発熱量で希嬏率を増加させた場合，及び等希釈率で投入発熱量を変化させた場合の $P_{\text {max }}$ と $T_{\text {max }}$ の変化を示す. 希釈率を変化させると $T_{\text {max }}$ の変化が大きく, 一方, 投入発熱量を変化させると $P_{\text {max }}$ の変化が大きくなる，低希釈率では温度が高いため，KI の圧力影響が大きい．そのため，投入発熱量が増加する と図 11 に示したように KI が大きくなる，一方，高希釈率では温度が低いため，KI の温度影響が大きく，圧力影 響が小さい. そのため, 投入発熱量を増加させても $K I$ の増加が小さかった. 従来から， $\tau$ は未燃混合気の圧力と 温度履歴により予測する方法が試みられている. 今回の結果から，KI は $\tau$ とは異なり，燃焼後の圧力と温度によ り記述できる可能性があることがわかった.

本論文では，圧縮自着火で発生する圧力振動をノックとして実験を行った，火花点火を用いた燃焼プロセスで は，火炎伝播の途中にエンドガスが自着火し，ノックが発生する。すなわち，本実験とは混合気の自着火発熱量 割合が異なる．自着火発熱量割合はノックを誘発する加振力と相関があると考えられ，大きいほどノック強度に 影響を及ぼす可能性がある，また，同一混合気において自着火発熱量が大きいことは，着火領域が大きいことを 示す．着火領域が大きいほど，式(1)の第 2 項である膨張による圧力上昇の緩和が小さくなり，ノック強度が大き くなると考えられる. 実際に, 今回解析したノック強度は, 火花点火エンジンで発生するノック強度に比べて大 きいが，これはノックを誘発した自着火発熱量割合が多いことが原因と考えられる．したがって，今後は，火花 点火エンジンを用いた燃焼実験を行い, 火炎伝播燃燒するエンジンにおける $K I$ に及ぼす希釈の影響や, $K I$ と $P_{\max }$ や $T_{\text {max }}$ の関係を明らかにする予定である。

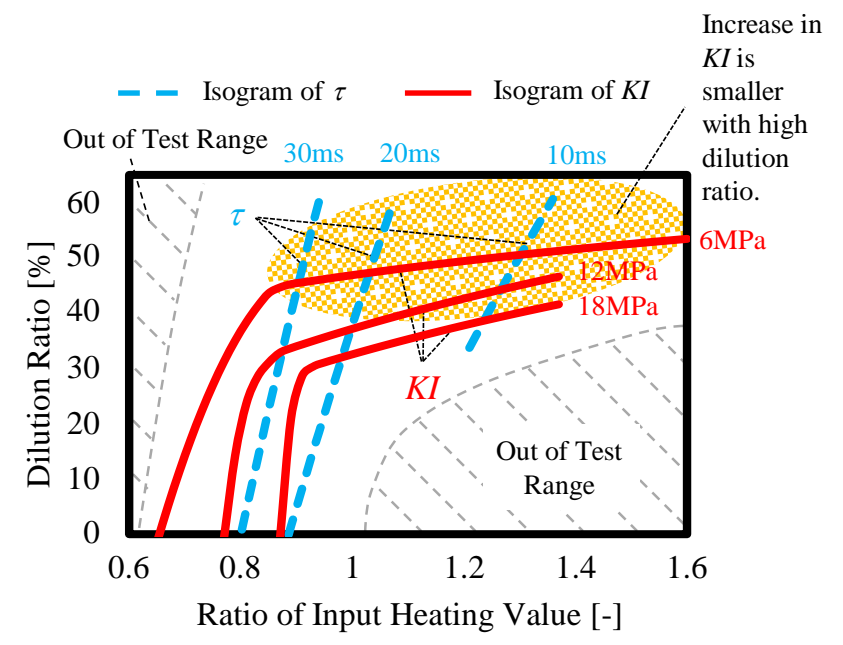

Fig.11 Effect of Input Heating Value and Dilution Ratio on $\tau$ and $K I$ (Isogram) 


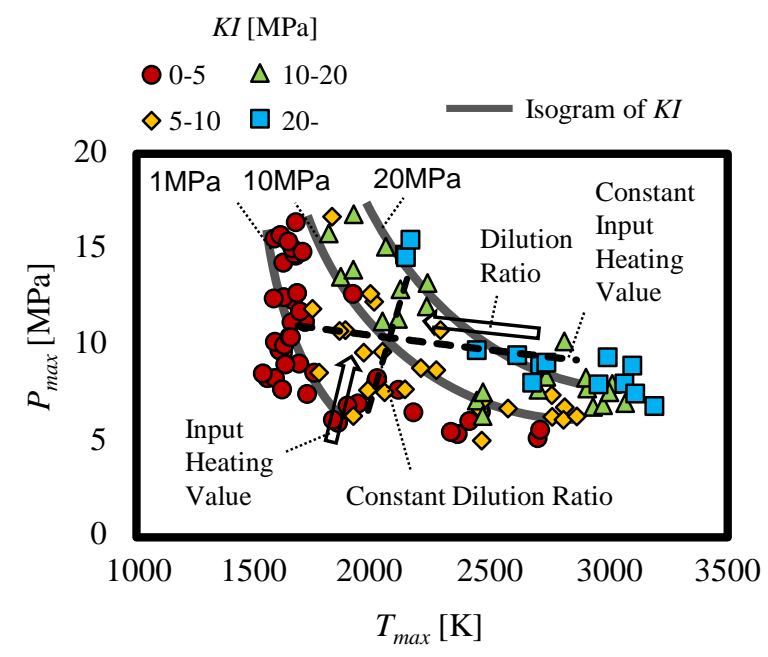

Fig.12 Effect of $P_{\max }$ and $T_{\max }$ on $K I$

\section{5. 結 言}

不活性ガスによる希釈が混合気自着火時のノック強度に及ぼす影響とノック強度の支配因子を調べた。その結 果，次のことがわかった.

・混合気が自着火した際のノック強度は不活性ガスの希釈により低下した。希釈率を高めると, 投入発熱量の増 加とともに自着火遅れは短くなるものの, ノック強度はあまり変化しなかった.

・ノック強度は, $P_{\max }$ と $T_{\max }$ で整理され， $P_{\max }$ もしくは $T_{\max }$ が大きくなった場合に大きくなることがわかった.

・ $T_{\max }$ が $2000 \mathrm{~K}$ 以下では八ック強度の温度感度が大きく, 圧力感度は小さかった. そのため, 高希釈条件ではノ ック強度が大きく低下し，投入発熱量を増加させてもノック強度はあまり増加しなかったと考えられる.

\section{References}

Azimov, U., Tomita, U., Kawahara, N. and Harada, Y., Premixed mixture ignition in the end-gas region (PREMIER) combustion in a natural gas dual-fuel engine: operating range and exhaust emissions, International Journal of Engine Research, Vol.12, No.5 (2011), pp.484-497.

Hickling, R., Chen, F. H. K. and Feldmaier, D. A., Pressure pulsations in engine cylinders, engine noise: excitation, vibration , and radiation, Plenum Press (1982), pp.3-37.

Inagaki, K., Fuyuto, T., Nishikawa, K., Nakakita, K. and Sakata, I., Dual-fuel PCI combustion controlled by in-cylinder stratification of ignitability, SAE Technical Paper 2006-01-0028 (2006).

Lawrence Livermore National Laboratory, Reaction Mechanism of Primary Reference Fuels (online), available from $<$ https:/combustion.llnl.gov/archived-mechanisms/surrogates/prf-isooctane-n-heptane-mixture>, (accessed on 28 May, 2014).

Splitter, D., Reitz, R. and Hanson, R., High Efficiency, Low emissions RCCI combustion by use of a fuel additive, SAE International Journal of Fuels and Lubricants, Vol.3, No.2 (2010), pp.742-576. 